\title{
A Novel Metal Supported SOFC Fabrication Method Developed in KAIST: a Sinter-Joining Method
}

\author{
Joongmyeon $\mathrm{Bae}^{\dagger}$ \\ Department of Mechanical Engineering, Korea Advanced Institute of Science and Technology, Daejeon 34141, Korea
}

(Received September 6, 2016; Revised September 20, 2016; Accepted September 21, 2016)

\begin{abstract}
Metal-supported SOFCs have been investigated to overcome the disadvantages of ceramic-supported SOFCs, including issues related to mechanical strength and sealing. In the case of ceramic-supported cells, the mechanical support is a brittle ceramic or cermet, and it contains expensive materials. However, metal-supported cells utilize ceramic layers that are only as thick as necessary for electrochemical functioning, thereby compensating for the disadvantages of ceramic-supported cells. The mechanical support is fabricated from inexpensive and robust metals, and the electrochemically active layers are applied directly to the metal support. The metal-supported SOFCs thus can provide a reduced system cost, ease of manufacturing, and operational advantages. Owing to these features, metal-supported SOFCs are a very promising candidate for commercialization. Given the importance of studying worldwide trends in metal-supported SOFC research for performance evaluation, this paper reviews development trends with a focus on fabrication methods. Furthermore, a novel fabrication method developed in KAIST is discussed.
\end{abstract}

Key words : SOFC, Metal-supported SOFC, Sinter-joining

\section{Introduction}

$\mathbf{S}$ OFCs are high-temperature fuel cells (with an operating temperature of approximately $1,000^{\circ} \mathrm{C}$.) that have used yttria-stabilized zirconia ( 8 mole $\% \mathrm{Y}_{2} \mathrm{O}_{3}, 8 \mathrm{YSZ}$ ) electrolyte for over 30 years with the perovskite $\mathrm{La}_{1-x} \mathrm{Sr}_{\mathrm{x}} \mathrm{M}$ $\mathrm{nO}_{3}(\mathrm{LSM})$ as a cathode and Ni-YSZ cermet as an anode. In contrast with other fuel cells, the high operating temperature enables direct electrochemical oxidation of hydrocarbons. This allows the use of various fuel sources such as $\mathrm{H}_{2}$, $\mathrm{CO}, \mathrm{CH}_{4}, \mathrm{CH}_{3} \mathrm{OH}$, and naphtha. In addition to these advantages, they offer a relatively long service life (approximately $60,000 \mathrm{~h}$ or 7 years) and have been verified in terms of thermal durability.

In the case of ceramic-supported SOFCs, which are being extensively studied, mechanical strength and thermal properties are achieved by using a thicker anode to control polarization characteristics. While the use of ceramic-supported SOFCs leads to enhanced electrical conductivity given their high operating temperature, they limit the use of metallic materials. This leads to constraints in not only lowering fabrication costs but also related to resistance to thermal shock, mechanical strength, and properties beneficial for commercialization such as miniaturization and lightweight. To overcome these issues, recent studies have focused on a

${ }^{\dagger}$ Corresponding author: Joongmyeon Bae

E-mail : jmbae@kaist.ac.kr

Tel : +82-42-350-3085 Fax : +82-42-350-3210 metal-supported integrated cell structure that provides satisfactory performance at low temperatures, as shown in Fig. 1. The two main advantages of metal-supported SOFCs are as follows.

(1) The significant decrease in thickness allows smaller and lighter cells.

(2) The use of a metal support (high strength, low cost) over ceramic (brittle and expensive) is advantageous in terms of mechanical strength, thermal properties, and costs.

Considering the importance of worldwide trends in metalsupported SOFC research for performance assessment, this paper reviews development trends with a focus on fabrication methods. Furthermore, a novel fabrication method developed in KAIST is discussed.

\section{Development Trends of Metal-Supported SOFCs}

Ceres Power Ltd. and Imperial College have jointly developed metal-supported SOFCs, reporting a power density greater than $0.3 \mathrm{~W} / \mathrm{cm}^{2}$ at $600^{\circ} \mathrm{C}$. Fig. 2 shows the fabrication process for SOFCs used by Ceres Power. The ferritic stainless steel is perforated to create a gas permeable region, and the fabrication process for ceramic-supported SOFC single cells is applied. The three-layer electrolyte consists of a cerium gadolinium oxide (CGO) layer $(\sim 20 \mu \mathrm{m})$ for mechanical integrity and gas-tightness, a thin-film YSZ layer to block electronic conduction, and a CGO buffer layer. 
For improved sintering of the CGO layer, cobalt oxide or copper oxide was used as a sintering aid. $\mathrm{Ni} /$ $\mathrm{CGO}(20 \sim 30 \mu \mathrm{m})$ was used as an anode, LSCF/ CGO $(10 \sim 30 \mu \mathrm{m})$ as a cathode, and Ti-Nb stabilized Cr alloy $(\sim 100 \mu \mathrm{m})$ as the metal support. ${ }^{1-2)}$

Plansee recently developed a metal-supported SOFC using an autonomously developed ITM substrate. The metal is fabricated on a porous metal attached to a metal plate at the boundary. This newly designed metal substrate showed good performance in protecting the metal, even upon exposure to high temperatures. Furthermore, to fabricate a dense electrolyte, YSZ/gadoliuia-doped ceria (GDC) sputtering was applied. They reported a power density of about $0.5 \mathrm{~W} / \mathrm{cm}^{2}$ at $820^{\circ} \mathrm{C}$. As shown in Fig. 3, the cell consists of an LSCF/GDC cathode, GDC buffer layer, YSZ electrolyte, Ni/YSZ anode, GDC diffusion barrier layer, and ITM metal support. ${ }^{3)}$

The German Aerospace Center (DLR) has fabricated thinfilm SOFCs on a porous metal support, as shown in Fig. 4, reporting a cell performance of $0.6 \mathrm{~W} / \mathrm{cm}^{2}$ at $800^{\circ} \mathrm{C}$. Ni felt and $\mathrm{Fe} / \mathrm{Cr}$ foam are used as the metal support, YSZ $(\sim 25 \mu \mathrm{m})$ as an electrolyte, $\mathrm{Ni} / \mathrm{YSZ}(\sim 35 \mu \mathrm{m})$ as an anode, and LSM $(\sim 30 \mu \mathrm{m})$ as a cathode. Vacuum plasma spray (VPS), dip-coating, and electron beam physical vapor deposition (EB-PVD) methods were applied to deposit the electrolyte on the metal support. ${ }^{4}$

As shown in Fig. 5, Topsoe fabricated metal-supported cells using a tape cast powder metal porous support and infiltrated nano-structured electrodes. The maximum output density was approximately $0.4 \mathrm{~W} / \mathrm{cm}^{2}$ at $650^{\circ} \mathrm{C}$. Metal powder containing $\mathrm{Fe}$ and $\mathrm{Cr}$ was used as the metal support to attain a thickness of less than $400 \mu \mathrm{m}$, and LSCF con-

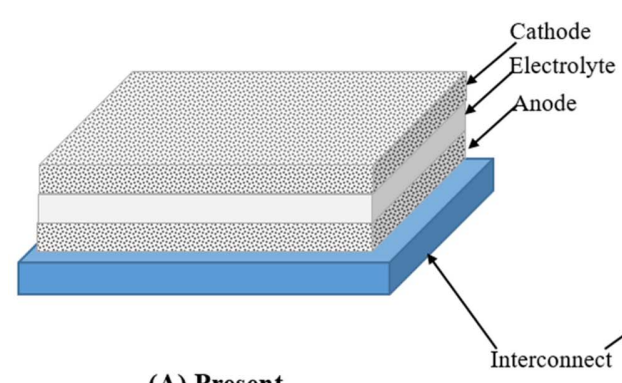

(A) Present

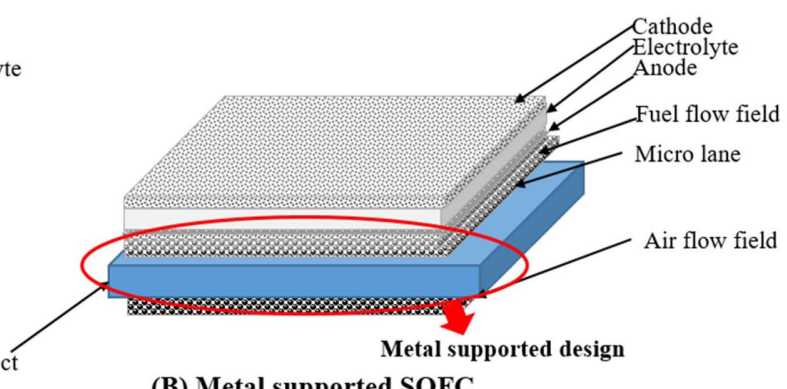

(B) Metal supported SOFC

Fig. 1. Present and new conceptual (metal supported) SOFC repeat unit.

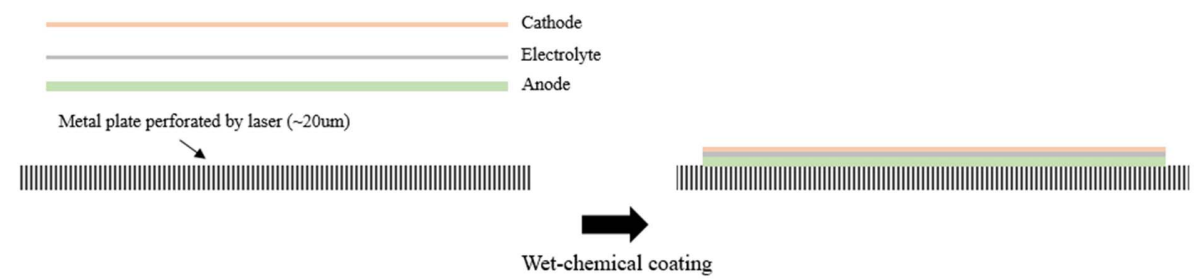

Fig. 2. Ceres Power Ltd. fabrication process for metal supported cell.

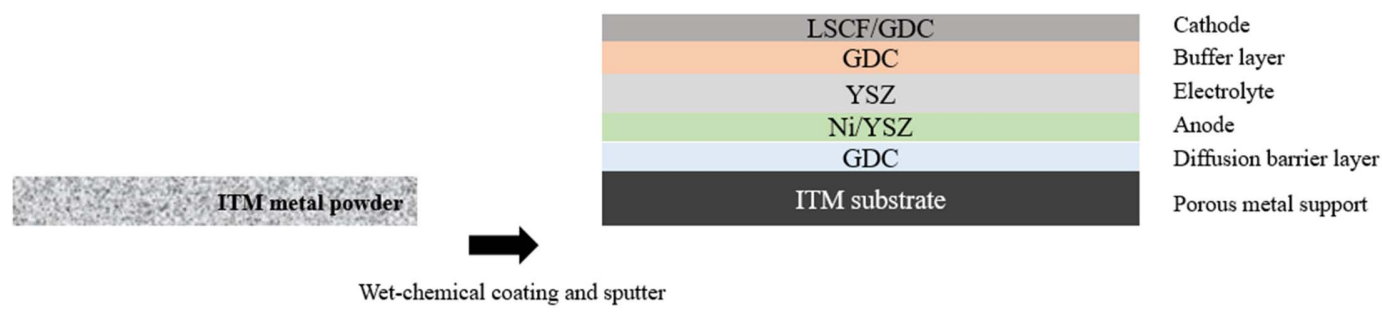

Fig. 3. Plansee fabrication process for metal supported cell.

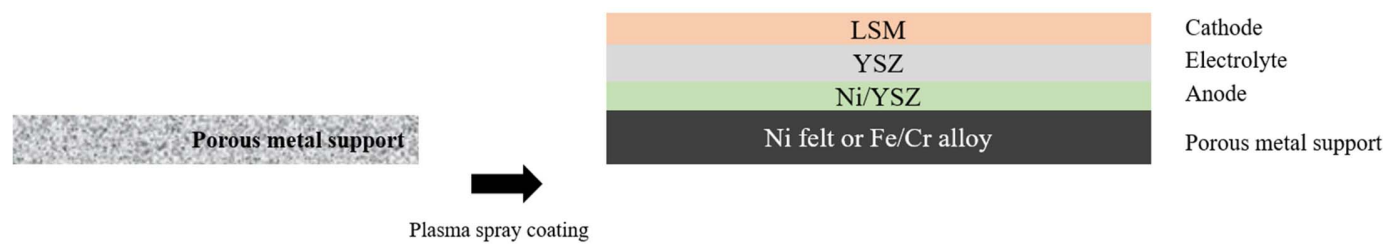

Fig. 4. DLR fabrication process for metal supported cell. 


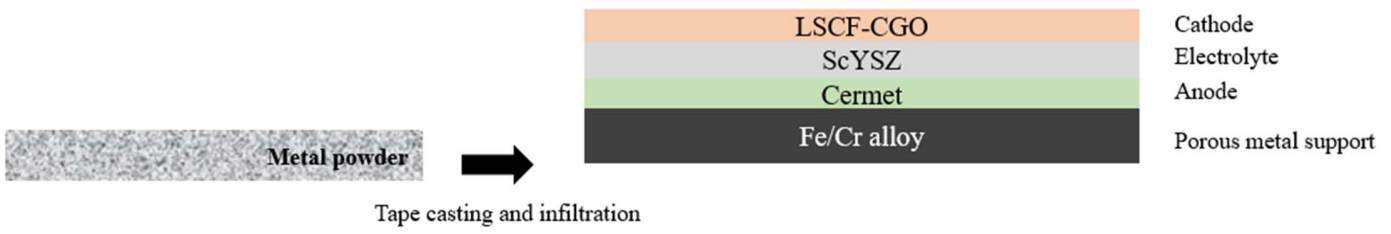

Fig. 5. Topsoe fabrication process for metal supported cell.

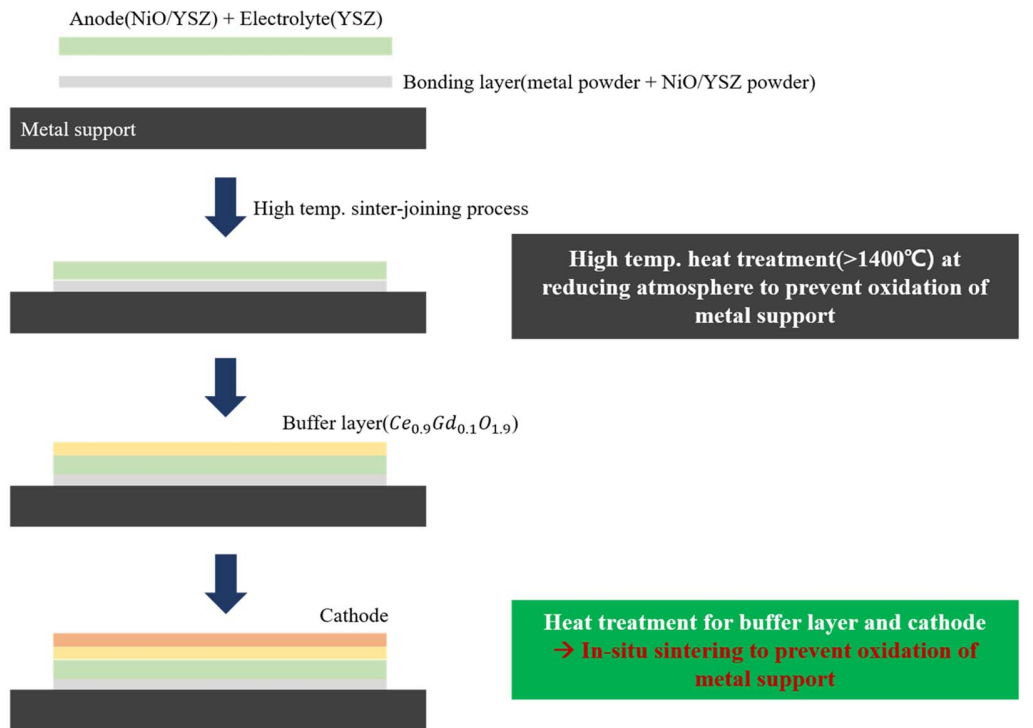

Fig. 6. Sinter-joining method of metal-supported SOFC single cell.

taining CGO was employed as the cathode material. ${ }^{4)}$

As outlined above, the leading groups in metal-supported cell research have used CGO-based electrolytes or adopted expensive fabrication processes such as vacuum plasma deposition or laser plasma. These high-cost techniques are inadequate for commercialization purposes. As such, more affordable fabrication processes are necessary for the commercialization of metal-supported solid oxide fuel cell stacks.

\section{A Novel Fabrication Method: Sinter-joining}

In KAIST, a new metal-supported SOFC has been developed to improve the yield of large-area cells and facilitate mass production. The suggested high temperature sinterjoining process (Fig. 6) conducts sinter-joining of the ceramic single cell and metal plate at high temperature. A bonding layer consisting of $\mathrm{NiO} / \mathrm{YSZ}$ and STS powder was introduced. The new metal-supported SOFC single cell enhances mechanical properties and minimizes the use of sealants when forming stacks. A low-cost process based on in-situ sintering was applied for the cathode and buffer layer, allowing large cells of $100 \mathrm{~mm} \times 100 \mathrm{~mm}$ to be fabricated more easily.

Figure 7 shows a $5 \times 5 \mathrm{~cm}^{2}$ metal-supported SOFC with stainless steel or Crofer22APU as the metal support. Both metals exhibit a high smoothness, and Crofer22APU
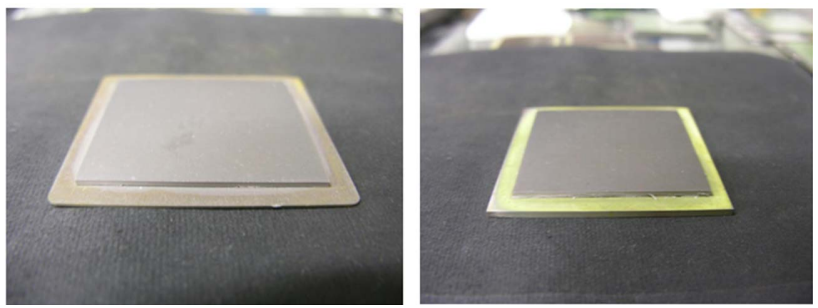

Fig. 7. Metal-supported cell made from Crofer (left) and SUS430 (right).

showed outstanding resistance to oxidation and deformation at high temperatures. As shown in Fig. 8, a power density of $0.5 \mathrm{~W} / \mathrm{cm}^{2}$ was achieved at $800^{\circ} \mathrm{C}$.

Large-area metal-supported cell fabrication technology with high smoothness is a key factor in stack design. At present, the thickness of metal supports and ceramic cells is less than $1 \mathrm{~mm}$, and the overall thickness of metal-supported cells can be maintained below $1 \mathrm{~mm}$ if high-strength ceramic cells are developed for metal-supported cells.

The fabrication of metal-supported cells is considered as a key technology for SOFC commercialization. While high costs and fabrication challenges have impeded commercialization, the suggested technique not only lowers the manufacturing cost for metal-supported cells but also enables the fabrication of large-area cells. 
Figure 9 shows the metal-supported bipolar plate, with inner manifolds, designed for the metal-supported SOFC stack. The plate was fabricated using metal plate brazing and diffused bonding technology.

To minimize the use of the sealant, which is a major problem in existing ceramic single cell stacks, metal-metal diffusion bonding and laser welding were applied to the metalsupported sheet and bipolar plate.

Figure 10 shows the metal-supported SOFC short stack fabricated for a performance evaluation. The $5 \times 5 \mathrm{~cm}^{2}$ metal-supported cell was placed in the bipolar plate and brazed for sealing. The results for long-term operation show that the cell performance drops by less than $1 \%$ when operated for $200 \mathrm{~h}$ at $800^{\circ} \mathrm{C}$.

As shown in Fig. 11, the overall stack size is $10 \times 10 \times 5 \mathrm{~cm}^{3}$ with a $50 \mathrm{~mm} \times 50 \mathrm{~mm}$ metal-supported single cell. The effective area of the single cell is $40 \mathrm{~mm} \times 40 \mathrm{~mm}$, or $16 \mathrm{~cm}^{2}$. The intake manifolds of air and fuel were verified through a

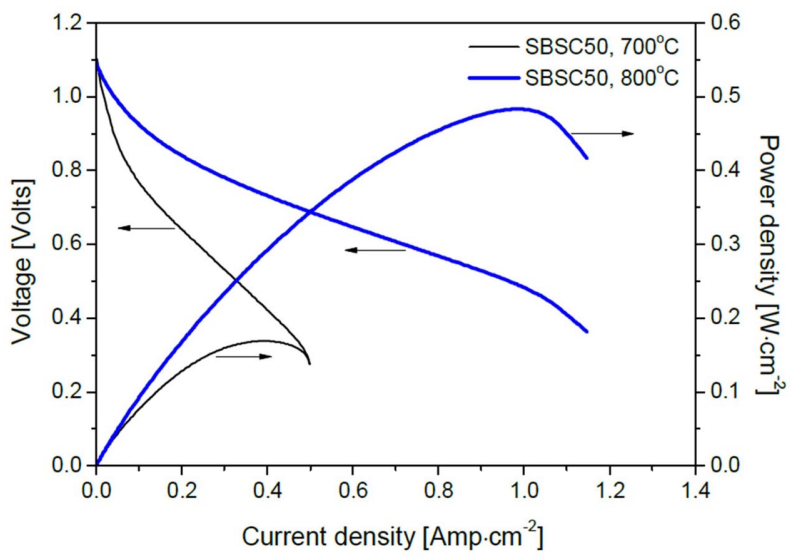

Fig. 8. Performance of a $5 \times 5 \mathrm{~cm}^{2}$ metal-supported SOFC fabricated from Crofer22APU.
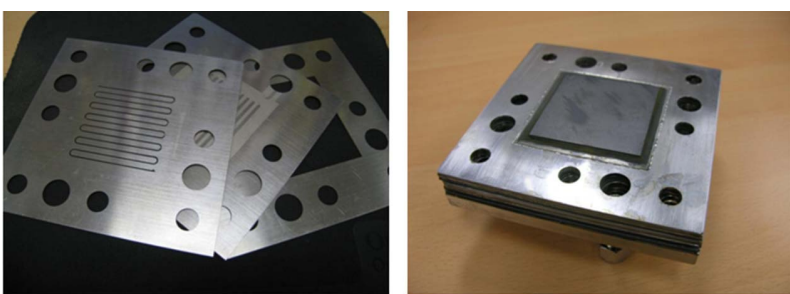

Fig. 9. Metal-supported SOFC bipolar plate (left) and a $5 \times 5 \mathrm{~cm}^{2}$ stack (right).
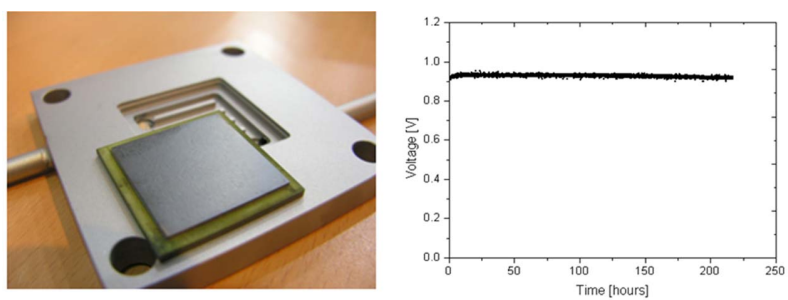

Fig. 10. A metal-supported SOFC short stack (left) and longterm operation characteristics (right) computational analysis, and the stack was designed such that air and fuel are supplied in a counter-flow configuration. Hydrogen sealing was achieved by welding the metal support and metal bipolar plate, and air sealing by MICA. Glass or ceramic sealants, commonly associated with problems in ceramic-supported stacks, were not used (Fig. 12).

To observe the practicality of the designed stack, a prototype was developed, as shown in Fig. 13. After investigating the possible problems, a $50 \mathrm{~mm} \times 50 \mathrm{~mm}$ metal-supported five-layer stack was fabricated. Currently, stack measurements are being taken, and the stack design will be reassessed based on the results. An $80 \mathrm{~mm} \times 120 \mathrm{~mm}$ stack will be developed followed by a performance evaluation.

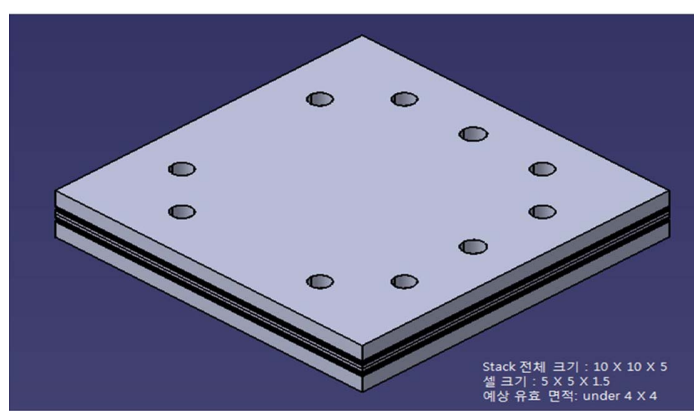

Fig. 11. Schematic diagram of a stack.

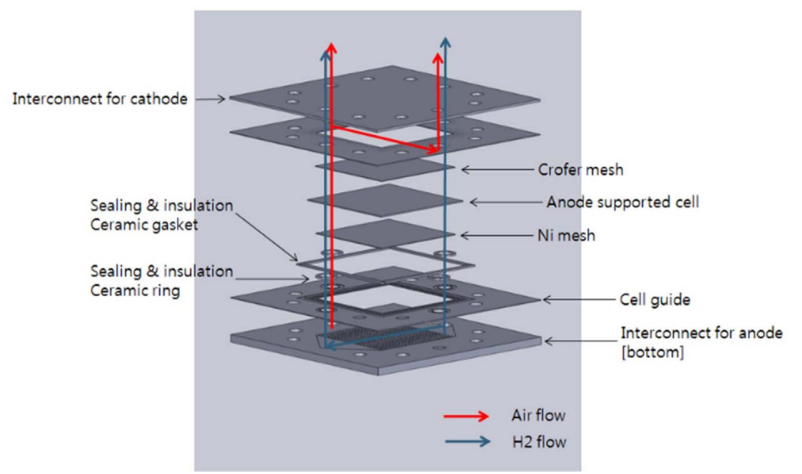

Fig. 12. Stack components and assembly.

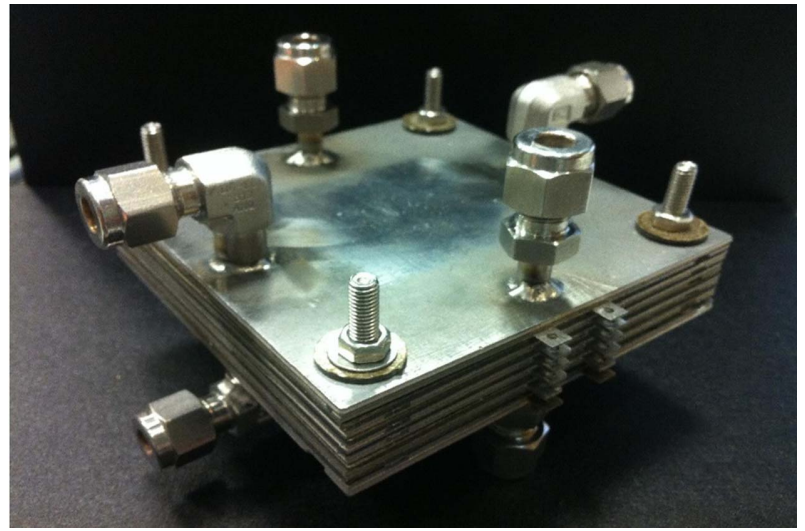

Fig. 13. A $50 \mathrm{~mm} \times 50 \mathrm{~mm}$ metal-supported five-layer stack. 


\section{Acknowledgements}

This work was supported by the Global Frontier R\&D Program on Center for Multiscale Energy System funded by the Nati0onal Research Foundation under the Ministry of Science, ICT \& Future, Korea(2011-0031569). This research was also supported by a grant from the Fundamental R\&D Program for Core Technology of Materials funded by the Ministry of Knowledge Economy, Republic of Korea. This work was also supported by the Industrial Strategic technology development program(10060209, Establishment of Technology Development Plans for Hydrogen Production Model \& Hydrogen-Resistance Materials for Ironmaking) funded By the Ministry of Trade, industry \& Energy(MI, Korea).

\section{REFERENCES}

1. R. Leah, A. Bone, M. Lankin, A. Selcuk, M. Rahman, A. Clare, L. Rees, S. Phillip, S. Mukerjee, and M. Selby, "Ceres Power Steel Cell Technology: Rapid Progress Towards a Truly Commercially Viable SOFC," ECS Trans, 68 [1] 95-107 (2015).

2. R. Leah, M. Lankin, R. Pierce, A. Bone, "Process for Forming a Metal Supported Solid Oxide Fuel Cell"; US Patent 20150064596 A1 (March 5, 2015).

3. Th. Francoa, M. Haydna, A. Weberb, W. Schafbauera, L. Blumc, U. Packbierc, D. Roehrensc, N. H. Menzlerc, J. Rechbergerd, A. Venskutonisa, L. S. Sigla, and H.-P. Buchkremerc, "The Status of Metal-Supported SOFC Development and Industrialization at Plansee," ECS Trans, 57 [1] 471-80 (2013).

4. G. Schiller, "Progress in Metal Supported Solid Oxide Fuel Cell"; in Proceedings of the International Symposium on Energy Materials: Opportunities and Challenges, Kolkata, 2011. 